\title{
Caesar's servitium amoris: Some comments on the references to Roman love poetry in Book 5 of Lucan's Civil War
}

Mariusz Plago

(University of Wroclaw)

\begin{abstract}
In his Civil War, Lucan enters into intertextual game not only with epic and tragedy, but also with love poetry. A number of references to Roman elegy, the Heroides, and Ariadne's lament in Catullus (64) have been noted in Book 5, when Caesar arrives in Epirus and summons his troops from Italy. The aim of this article is to examine the functions of these elegiac references related to Caesar and to propose an interpretation slightly different from that found in earlier studies. Using elegiac vocabulary, motifs, and topoi (servitium and militia amoris) in 5.476497, Lucan makes his audience perceive Caesar in the role of an elegiac mistress (domina), who thereby imposes the role of lover on his soldiers. However, those roles do not correspond to their real meaning in the poem as Caesar is quickly forced to transform into a lover. This shift is crucial for the intertextual game with love poetry. Nevertheless, the troops do not notice the change, standing by the role they were previously cast in (5.678-699). In this way, they allow their leader to become a mistress again and continue the war.
\end{abstract}

\section{Keywords}

Lucan; Caesar; civil war; servitum amoris; militia amoris; Roman elegy; Heroides; Hero; Leander 
Halfway through Book 5 Caesar sails from Brundisium to Greece, where his and Pompey's armies are encamped opposite each other (461-475). Instead of a narration about military actions, the audience encounters two extensive passages focusing first on Caesar (476-702), and then on Pompey (722-798), of which the keyword is mora, delay in the war. ${ }^{1}$ Both passages describe the reasons drawing the leaders away from the fight, and the efforts to overcome the delay. In this way they constitute exhaustive characterisations of the commanders, who for the first time stand against each other in the war (at the end of Book 2 Pompey was in a fortified city whose seaport Caesar tried to block). Caesar, overwhelmed with a thirst for war, is held back from committing a crime because of the army in Italy led by Antony: Caesaris attonitam miscenda ad proelia mentem / ferre moras scelerum partes iussere relictae ("Though Caesar was frantic to join forced to endure a postponement of wicked the partisans he had left in Italy", ${ }^{2} 476-477$ ); whereas Pompey's mind is occupied with his love for Cornelia

... heu, quantum mentes dominatur in aequas

iusta Venus! dubium trepidumque ad proelia, Magne,

te quoque fecit amor... (Lucan. 5.727-729).

"Ah! how mighty is the power of wedded love over gentle hearts! Even Magnus was made anxious and afraid of battle by his love..."

Caesar tries to shorten the delay - he first incites the reluctant (morantem, 480) Antony, then, growing impatient, attempts to cross the Adriatic Sea himself, and is prevented by a massive storm; Pompey would like to linger further, but after Antony's arrival he is forced to send Cornelia away from the camp: ... blandaeque iuuat ventura trahentem / indulgere morae... ("... he preferred to post pone what must come, to yield to the allurements of delay...”, 732-733). Both episodes end with the defeat of the obstacle - Antony's landing (703-721) and Cornelia's sailing away to Lesbos (790-805).

The passages share yet another similarity - their erotic dimension. In the case of Pompey amor is spoken of directly $(728-729,748,763,794)$; the erotic nature of the lines relating to him and his wife is obvious. Pompey sends Cornelia from the camp because the troops from Brundisium under Antony's command had already come to Caesar and the war could not be delayed. The conversation between husband and wife takes place at dawn, in bed. In this passage, scholars have found references to, for example, the farewell of Hector and Andromache in the Iliad (Hom. Il. 6.390-502), ${ }^{3}$ to Ovid's story of Ceyx and Alcyone (Met. 11.410-748), ${ }^{4}$ and to Roman elegiac poetry. ${ }^{5}$ Interestingly, in

1 For mora as Lucan's narrative strategy see Bramble (1982: p. 540); Henderson (1987: p. 134), Masters (1992: p. 9).

2 All translations from Lucan's Civil War are by Duff (1928).

3 Hutchinson (2013: p. 331).

4 Bruère (1951: pp. 222-226).

5 Sannicandro (2010: pp. 43-82) - Propertius' Arethusa (4.3) and the heroines from Ovid's Heroides; McCune (2014: pp. 185-191) - Roman elegiac poetry in general (Cornelia as one of the abandoned heroines); on Cornelia in Lucan's Book 8 and the Propertian Arethusa, see also Caston (2011: pp. 142-146). 
Caesar's case, we also find a number of references to Roman love poetry, when he calls upon Antony to come to Epirus (Lucan. 5.476-497), as well as when he returns to the camp and hears out his soldiers' complaints (5.678-699).

Firstly, the scenario itself, when Caesar, who is eager for war, is in his camp near the sea, impatiently awaits the soldiers and summons Antony, evokes associations with such figures as Catullus' and Ovid's Ariadne or Ovid's Hero, who looking out to the sea call to their lovers. Cicero's words can serve here as confirmation that the situation in which Caesar finds himself can be easily interpreted in an erotic way. When he learns that Pompey had departed from Brundisium (Att. 9.6.2; which was not actually true, since Pompey was still waiting for the return of the ships which had crossed the Adriatic with consuls, a part of the army and civilians), he presents himself and Pompey as lovers. Pompey, by his deeds, by his escape, detached him from love:

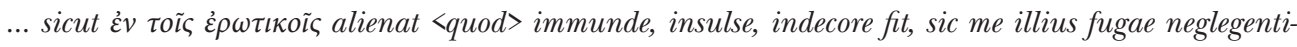
aeque deformitas avertit ab amore. (Cic. Att. 9.10.2)

“... as en choses d'amour, anything uncleanly, uncouthly, unsuitably done alienates, so the ugliness of his flight and discourtesy turned me from my affection.” (trans. by Shackleton Bailey 1968)

Cicero, however, adds immediately that now, after Pompey's departure, his love is reborn, he cannot bear the longing, he is like that (ille) bird (of Plato) ${ }^{6}$ looking towards the sea:

nunc emergit amor, nunc desiderium ferre non possum, nunc mihi nihil libri, nihil litterae, nihil doctrina prodest. ita dies et noctes tamquam avis illa mare prospecto, evolare cupio. (ibidem)

"But now my affection comes to the surface, the sense of loss is unbearable, books, writing, philosophy are all to no purpose. Like Plato's bird I gaze out over the sea day and night, longing to take wing." (trans. by Shackleton Bailey 1968)

The perception of the similarities between Caesar and such characters as the heroines of Ovid's Heroides was facilitated by the fact that Caesar had a very close relationship with his men. The soldiers were extremely devoted to him and ready to endure many hardships and sacrifices on his behalf. Such devotion is seen in Lucan when the troops in Epirus complain that Caesar abandoned them and they risked death, trying to cross the Adriatic. In this case, considering the elegiac references, we can think about a lover's lament. In the Life of Caesar, Plutarch depicts troops heading to Brundisium and muttering against Caesar because of the superhuman effort they are required to make (37.5-7) - they do not want to cross in winter when the sea is rough. After arriving at the port, already abandoned by Caesar, they accuse themselves of treason and the commanders of tardiness. Sitting on the coastal rocks and looking in the direction of Epirus, they wait for ships to sail to Caesar:

6 On the allusion to Pl. Ep. 7.347e-348a, see Gildenhard (2006: pp. 203-205). 


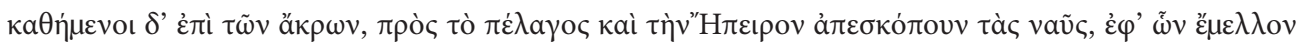

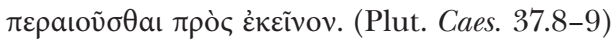

"Then, sitting on the cliffs, they looked off towards the open sea and Epirus, watching for the ships which were to carry them across to their commander." (trans. by Perrin 1919)

Ch. Pelling in his commentary noted that the soldiers at Brundisium resemble Odysseus sitting on a rock, on Calypso's island (Hom. Od. 5.151-153), but also Ariadne (Catull. 64.126-131; Ov. Epist. 10.25-28) or Hero (Ov. Epist. 19.21-22). We can add Phyllis (Ov. Epist. 2.121-126) and Oenone (Ov. Epist. 5.61-64), who also sit on the shore. On the other hand, according to Fantham (1985: p. 131), “... the soldiers act like erastai toward their beloved Caesar...”. Certainly, some role in Lucan's use of elegiac references may also be played by the fact that Caesar was accused of bi-sexuality. Not only did his enemies talk about his affair with Nicomedes, king of Bithynia, but his men were also supposed to have sung couplets on this subject during the Gallic triumph (Suet. Caes. 49).

In addition to the general scenery, there are also many motifs common in Roman love poetry and Lucan's passages (such as requests for arrival, complaints of tardiness, insinuation of infidelity, lack of appreciation of looming dangers; in the case of the soldiers - complaints about abandonment or assurances of readiness to sacrifice their lives, making the value of their lives dependent on another person). Of course, we can find such motifs elsewhere, in other situations, especially military-related, in other genres. Leigh (1997: p. 205), writing about Laelius, Caesar's centurion, who appears in Book 1 and encourages the hesitant troops to participate in the civil war (1.352-391), notes: "The readiness to endure any geography in pursuit of the addressee may echo the terminology of the military sacramentum, but it is also used for the devoted loyalty of friends, in a propempticon, in an epicedion, and, most frequently, to express the devotion of one lover, often an elegist, for another." Here the case looks similar.

The third vital element in Lucan's intertextual play (apart from the general scenery and a number of motifs) is the key vocabulary shared with Roman elegiac poetry, of which the two essential words are: mora and querela (or querella). In love poetry, the aforementioned mora, the crucial term in the passages taking place in the camps of Caesar and Pompey, usually means a delay in meeting or separation of lovers, which must be overcome as soon as possible. ${ }^{7}$ Querela functions almost as a technical term for elegy, including the Heroides. ${ }^{8}$ When Lucan's Caesar returns to the camp after an unsuccessful attempt to cross the sea, the words of his soldiers are a lament or a complaint: querellis, 5.681. He himself complains (5.491; conqueror) that the time of destiny is being lost. Caesar's speech structurally and thematically, by way of contrast, corresponds to the speech of Pompey to his wife (5.739-759), and the lament of the soldiers is reflected by the lament of Cornelia (5.761-790; querellas, 761). Roman elegy itself used extensively

7 For mora in Roman elegy see Pichon (1902: s.v.).

8 E.g. Prop. 1.18.29: et quodcumque meae possunt narrare querelae. For querela in Roman elegy see Saylor (1967), Baca (1971), and James (2003: pp. 108-121). For possible references in the soldiers' speech to Dido's lament in Vergil see Matthews' comments (2008: ad 681, 687, 692). In Book 4 Vergil himself draws from elegy while constructing the character of Dido, see Cairns (1989: pp. 129-150). 
military imagery and developed the topos of militia amoris, in which a lover was compared to a soldier. Lucan seems to reverse the process: he uses erotic imagery in a military context.

The erotic aspect of the scene where Caesar addresses Antony was first analysed by M. Matthews in her commentary on 5.476-721, and then in a separate article (Matthews 2008 and 2011). She notes many parallels to Catullus 64 (Ariadne $\sim$ Caesar), Roman love elegy, and Ovid's Heroides, Leander and Hero's letters in particular (Epist. 18 and 19). Caesar (who, wishing to shorten delay, mora, that is the time of separation, writes a letter of sorts to Antony $)^{9}$ is depicted "...in the role of the familiar abandoned heroine of earlier literature addressing her departed lover from the sea-shore” (Matthews 2011: p. 122). The same role is adopted by his soldiers when he returns to the camp (Matthews 2008: ad 678-99). According to Matthews, due to the evocation of love poetry, the relationship between the leader and the troops assumes an almost erotic character; moreover, such a depiction of "the normally über-masculine, epic hero Caesar [...] is particularly effective" (Matthews 2008: p. 17). ${ }^{10}$ Lucan also presents the leader "as sexually ambiguous", which aligns with the sources and may characterise him as an eastern tyrant; such innuendo was a popular political insult in the late Roman Republic (Matthews 2008: ad 480-97). Similar accusations are mentioned by C. Littlewood (2016), who also devoted much attention to the erotic undertone of Lucan. 5.480-497 and 678-699, setting forth more parallels with Roman love poetry. To him, however, the most important fact is that Lucan blurs the boundaries between the private and the public sphere. Caesar becomes everything (omnia Caesar erat, Lucan. 3.108): "One of the ways of representing this abomination is to characterise Caesar as an elegiac lover, to represent his alliances and his voice as personal" (Littlewood 2016: pp. 167-168). ${ }^{11}$

The remarks of Matthews and Littlewood can be modified to some extent. The essence of the intertextual play with love poetry is the difference between the roles assumed by the characters, Caesar and his soldiers, and their true nature in the poem. Yes, Caesar first plays the role of a mistress for his troops and for Antony, resembling Ariadne and Hero in particular, although not entirely in the way observed by Matthews. But when Antony does not arrive, Caesar attempts to cross the sea, adopting the role of a lover obeying his beloved. Matthews notes this change, but does not give it the attention it deserves. This change is of paramount importance to our understanding of Lucan's intertextual play with Roman love poetry. ${ }^{12}$ My remarks are based to a large extent on the observations of L. V. Pitcher, who, writing about the relationship between Caesar and his soldiers in the storm-scene in Book 5, stresses that "the crucial role [is]

9 According to Matthews (2008: ad 481) "[h] ere Caesar seems to be composing a letter in the manner of the heroines of Ovid's Heroides." Cf. Caes. Civ. 3.25.3: ... permotus Caesar Brundisium ad suos severius scripsit...

10 On the close relationships between Caesar and his soldiers, see Leigh (1997: pp. 191-210).

11 Many of the parallels mentioned in this article are quoted by Matthews (2008 and 2011) and Littlewood (2016). I shall take the liberty of omitting each further case in the footnotes.

12 Matthews (2008: ad 480-97, 501, 502-3); she also notes temeritas that characterises Caesar (5.501, 682), as well as Leander, Ov. Epist. 19.87. Lucan mentions expressis verbis the myth of Leander in 9.954-955, when Caesar sails through the Hellespont. 
played in it by Caesar's audience, his men, and their (mis)understanding of what he is about..." The troops overestimate the importance of the leader and underestimate their own, so the Republic is doomed (Pitcher 2008: pp. 248-249). Pitcher analyses 5.504-702 in the context of the earlier scenes. The first is the scene from Book 4, when in Spain Caesarians and the troops loyal to Pompey (commanded by Petreius and Afranius) camp close together and begin to fraternize (168-253). This moment of peace is brutally interrupted by Petreius and his men. The second is the mutiny of Caesar's troops in Book 5 (237-373). When returning from Spain, Caesar's soldiers start a revolt, seeking recognition of their merits in the war and of themselves as accomplices in crime. The mutiny is quickly quelled by the leader. ${ }^{13}$ Pitcher omits the intertextual references, however, which in fact support his interpretation.

Introducing the "letter" to Antony, Lucan's narrator states that Caesar often summoned his officer with requests and threats: illum saepe minis Caesar precibusque morantem / evocat ("Again and again Caesar urged him to haste with threats and entreaties", Lucan. 5.480-481). Trying to acquire something through threats and requests is not unusual in a military or political context. In Livy's Book 4, distinguished plebeians accuse patricians of abusing this method of political struggle: si plebi respirare ab eorum mixtis precibus minisque liceat (Liv. 4.25.12). The phrase minis precibusque also has erotic connotations. It may suggest that Caesar appears as a lover begging and threatening to win an unyielding woman. Ovid's L. Tarquinius pressures Lucretia in this way (instat amans hostis precibus, pretioque, minisque, Fast. 2.805). ${ }^{14}$ The lyrical subject of the Amores similarly tries to overcome the resistance of the ianitor when he stands before the door of his puella (nec te precibusque minisque / movimus, Ov. Am. 1.6.61-62). Taking into account further narration, Caesar will in fact become a lover, thus the lines may be proleptic, but they are now at odds with Caesar's elegiac role, which the audience decipher rather as a feminine one. In his quasi-letter to Antony, he clearly sets the attitude of his commander in Italy against the attitude of the soldiers themselves. He accuses Antony of holding the men back with his delay. He downplays the risks, stating that they are not, after all, divided by the Syrtes (Lucan. 5.484-485), which in Latin poetry are used as a synonym for a dangerous sea. ${ }^{15}$ The troops do not display any such fears, they will come even "at the cost of shipwreck" (Haskins 1887: ad loc.):

O mundi tantorum causa laborum,

quid superos et fata tenes? sunt cetera cursu

acta meo, summam rapti per prospera belli

te poscit fortuna manum. non rupta vadosis

Syrtibus incerto Libye nos dividit aestu.

numquid inexperto tua credimus arma profundo

inque novos traheris casus? ignave, venire

13 On this episode, see esp. Fantham (1985).

14 Cf. Liv. 1.58.3: tum Tarquinius fateri amorem, orare, miscere precibus minas, versare in omnes partes muliebrem animum.

15 In Roman elegy: Prop. 2.9a.33; 3.19.7; 3.24.16; Tib. 3.4.91; Ov. Am. 2.11.20; 2.16.21. 
te Caesar, non ire iubet. prior ipse per hostes

percussi medios alieni iuris harenas:

tu mea castra times? pereuntia tempora fati

conqueror, in ventos inpendo vota fretumque.

ne retine dubium cupientis ire per aequor:

si bene nota mihi est, ad Caesaris arma iuventus

naufragio venisse volet. (5.481-494)

"On you lies the blame for the sore troubles that afflict mankind; why do you arrest the course of destiny and the will of Heaven? All else has been done with my accustomed speed, and Fortune now demands of you the finishing touch for a war that has rushed on from victory to victory. We are not parted by the shifting tides of Libya - Libya whose coast is broken by the shoals of the Syrtes. Am I risking your army on a sea I have not tried, or drawing you into dangers unknown? Coward! Caesar bids you come, not go. I myself went before through the midst of the enemy, and my prow struck a shore that others controlled; do you fear my camp? I complain that you waste the hours granted by destiny; I spend my prayers upon the winds and waves. Check not the hearts that are eager to cross the treacherous main; the soldiers, if I know them, will be willing to join my forces at the cost of shipwreck."

Naufragium (494) is an important internal reference, as it recalls the topos of the state as a ship, introduced and inverted in Book 1 (499-504): the ship is abandoned by all when the storm, that here is Caesar, comes. The demise of the ship is therefore essentially a destruction of Rome. What is more, lines 492-493 in the context of Roman elegy evoke the image of a lover who is able to overcome the greatest obstacles, including a storm at sea and a shipwreck, in order to be with his beloved. Propertius mentions naufragium when he enumerates the Herculean tasks which a lover should be able to perform without hesitation: ... et naufragus ebibat undas (Prop. 2.24b.27). Hercules, who functions in the elegy as an exemplum, an element of the topos of servitium amoris (when he served Omphale), ${ }^{16}$ was not a shipwreck survivor, but a lover may become one. ${ }^{17}$ In Ovid's Am. 2.16, the lover with his mistress, domina, at his side, is also ready to cross the Syrtes (cum domina Libycas ausim perrumpere Syrtes; "Were my lady-love with me, I should dare to steer my ship through the Libyan Syrtes," ${ }^{18} 2.16 .21$ ) and be shipwrecked, which is illustrated by the myth of Hero and Leander:

saepe petens Hero iuvenis transnaverat undas;

tum quoque transnasset, sed via caeca fuit. $(2.16 .31-32)^{19}$

"Full oft the young lover had swum across the waters to see his Hero; the last time, too, he would have swum across, but the way was blind."

16 See Prop. 3.11.17-20; Ov. Epist. 9.73-81; Ars 2.217-222. For gods-slaves as examples of servus amoris in Roman elegy see Copley (1947: pp. 291-293); Murgatroyd (1981: pp. 598-600).

17 Richardson, Jr. (2006: ad loc.).

18 All translations from Ovid's Amores are by Showerman (1914).

19 On this Ovid's elegy see in particular Weiden Boyd (1997: pp. 53-67; on Hero and Leander, pp. 60-61). 
Hero herself notes in her Ovidian letter that Leander wants to swim, even though the sailors are afraid to cross the Hellespont, as the ship is usually destroyed in such weather: exitus hic fractis puppibus esse solet (Epist. 19.186). The young man, however, does not fear becoming "shipwrecked" as long as the sea casts his limbs (naufraga membra) on Hero's shore (Epist. 18.198). In Propertius' elegy 3.24, where the lyrical subject renounces his love for Cynthia, the amator is not only a shipwrecked sailor (naufragus, 3.24.12) in the Aegean Sea, but also Venus' slave: vinctus eram versas in mea terga manus, 3.24.14). When he regains his senses, he crosses the Syrtes (traiectae Syrtes, 3.24.16) and reaches the harbour. The lover's willingness to sail across stormy seas is also an element of the militia amoris topos (closely connected with servitium amoris) in the Amores 1.9.11-14, where Ovid equates amor to militia, a lover's and a soldier's life. ${ }^{20}$

Lucan has reversed the topos. Now the troops, sacrificing their lives for their leader, are like lovers, and Caesar plays the role of a mistress (domina) who cannot bear separation and delay (mora); ${ }^{21}$ such a role must be accepted by the soldiers without reservation, making them obedient slaves. Caesar also assumes the role of a mistress before Antony. ${ }^{22}$ The command ignave, venire / te Caesar, non ire iubet (487-488) resembles typical invocations from love poetry. In Propertius' elegy 3.6, Cynthia orders her lover in a letter to come without undue delay:

Nox media, et dominae mihi venit epistula nostrae:

Tibure me missa iussit adesse mora (Prop. 3.16.1-2)

"Middle of the night, and a letter comes from my mistress: / she has ordered me to be present at Tibur without delay..."23

Such a call is expected to appear on the tablets from Corinna in Ovid's Amores: hoc habeat scriptum tota tabella 'veni!' (1.11.24). Briseis awaits this order from Achilles: domini iure venire iube! (Ov. Epist. 3.154). With those same words begin the letters of Penelope: ipse veni! (Ov. Epist. 1.2) and Hero: (... veni! / longa mora est nobis omnis, quae gaudia differt (“... come! / For me all delay that puts off our pleasure is long”;24 Ov. Epist. 19.2-3).

The tone of her letter swings from subdued, filled with warnings, and fear for her lover, to a harsher one, with complaints about tardiness and demands for his arrival. Her words calling the young man to dismiss her warnings illustrate this well:

Me miseram! cupio non persuadere, quod hortor

sisque, precor, monitis fortior ipse meis (Ov. Epist. 19.187-188).

20 McKeown (1995: pp. 297-298) notes that it is Ovid's innovation.

21 Matthews (2008: ad 480) quotes passages from Hero's letter (Ov. Epist. 19.20.70).

22 Cicero presents Antony as a slave to Caesar, talking about Lupercalia of 44 BCE in Philippics 2 (... supplex te ad pedes abiciebas [sc. Caesaris]. Quid petens? ut servires? Tibi uni peteres qui ita a puero vixeras ut omnia paterere, ut facile servires..., 2.86).

23 All translations from Propertius are by Katz (2004).

24 All translations from Ovid's Heroides are by Murgatroyd \& Reeves \& Parker (2017). 
"Poor me! I want to fail to persuade you in urging caution,

and I pray that you're strong enough to withstand my warnings"

Ph. Hardie (2002: p. 142), discussing letters 18 and 19, writes about the difference between "the more masculine, active outlook of Leander, and the more feminine, passive, timorous outlook of Hero". M. Matthews (2011: pp. 133) similarly views the difference between Caesar as Hero in his speech and Caesar as Leander when trying to cross the Adriatic: "Caesar is at one moment the helpless female and at the next the daredevil man”. E. J. Kenney (1996: p. 15) describes Hero as "the most vulnerable of Ovid's three heroines [sc. Helen, Hero, Cydippe].” Hero's portrait, however, is more complex. Conflicting feelings - that make her rather the most tragic of the three heroines - torment her and thus her character and her letter can be interpreted in two ways: "This epistle may be a conscious and deliberate attempt to get him [sc. Leander] to brave the sea. But it could also be that she is so naive and impetuous and unreflecting that she drives him to make the crossing without really meaning to do that" (Murgatroyd \& Reeves \& Parker 2017: p. 227). If we take into account that Hero asks Leander not to listen to her warnings, it seems that this first interpretation is a little more credible.

Matthews (2011: p. 131) rightly notes that Lucan chose the Ovidian letters of Hero and Leander because of the storm, which is an essential element in the history of these lovers (although Ovid does not narrate it). ${ }^{25}$ In addition, Leander's egotism and Hero's self-abnegation in love, ${ }^{26}$ also perfectly describe Caesar, overcome by lust for war, in a speech to Antony and his attempt to cross the Adriatic. Hero, however, is not only an abandoned woman, but in her tenacious and even harsh insistence, she also acts like a mistress, domina, demanding obedience, as familiar in Roman love elegy. Leander, after all, refers to his beloved as domina several times (nunc etiam nando dominae placuisse laboro, Epist. 18.95; and 118, 164, 176). In this Caesar resembles her too.

In Hero's letter we find all the accusations known from Caesar's "letter" - fear of crossing, delay, betrayal. According to Caesar, as has already been mentioned, an obedient soldier-lover should pass through the Syrtes (Laelius, the aforementioned miles amator from Book 1, did not hesitate to do so: duc age [...] per inhospita Syrtis / litora... ("Lead us straightway through [...] the inhospitable shore of the Syrtes..."; Lucan. 1.367-368); Antony, however, does not undertake a crossing even through waters that are already known. Previously Caesar hacked through his enemies and landed on a shore occupied by others (percussi, 489, he defeated it militarily). Thus, he asks whether his officer is afraid of his camp: tu mea castra times? (490). The phrase may also have an erotic undertone. ${ }^{27}$ In Ov.

25 Matthews (2008: p. 17, ad 480-97, ad 491) and (2011: p. 132) describes Caesar as standing on the seashore while putting into words the "letter" to Antony. We can of course have that impression, but Lucan's text rather implies that he is in the camp, in a tent. He goes to the shore once he decides to cross the sea (5.504-514). Similarly, while composing the letter, Hero dwells in her tower, and only mentions sitting on the rock on the seashore (Ov. Epist. 19.27-28.).

26 The terms used by Kenney (1996: p. 15).

27 For example Prop. 1.7.15 (quod si vera meae comitarem castra puellae); 2.10 .19 (in opposition to 1. 4); Tib. 2.3.34; Ov. Am. 1.2.32; 1.9.1, 44; 2.18.40; Ov. Epist. 7.32. 
Epist. 19.65-90 Hero accuses Leander of being afraid to swim, although he did so when the waters were stormier:

nam memini, cum te saevum veniente minaxque

non minus, aut multo non minus, aequor erat; [...]

unde novus timor hic, quoque illa audacia fugit? (Ov. Epist. 19.85-86, 89)

"I remember when the sea was no less fierce and

threatening, or not much less, but you came, [...]

Where does this new fear come from, where has that daring gone?"

He is a deserter who should come back to his camp (in tua castra redi, socii desertor amoris, 157). There is no reason to be afraid (quod timeas, non est! 158), because the courageous one (auso, ibid.) is going to win the favour of Venus herself, who will calm the sea. Lucan's Caesar bemoans the missed opportunities for the crossing and prays for a peaceful sea and wind (or perhaps he wastes his prayers as he begs): pereuntia tempora fati / conqueror, in ventos inpendo vota fretumque ("I complain that you waste the hours granted by destiny; I spend my prayers upon the winds and waves"; 5.490-491). ${ }^{28}$ Hero laments that Leander did not begin to swim when the winds were calmer: nocte sed hesterna lenior aura fuit. / cur ea praeterita est? (“... but last night the wind was gentler. / Why was that ignored?"; Epist. 19.72-73). She also prays to Neptune to smooth the surface of the sea (19.129-146).

Finishing his "letter" to Antony, Caesar, fearing disloyalty, also formulates clear political charges against him. He himself shares the power over Epirus with the Senate, while his officer has the entirety of Italy:

iam voce doloris

utendum est: non ex aequo divisimus orbem;

Epirum Caesarque tenet totusque senatus,

Ausoniam tu solus habes (Lucan. 5.494-497).

"I must even use the language of resentment: the division of the world between us is unfair:

Caesar and all the Senate share Epirus between them, while you keep Italy all to yourself."

In elegy mora may also be interpreted by a mistress as betrayal. For example, in Propertius' 3.23, the amator imagines what could have been written on the lost tablets from his beloved:

fortisan haec illis fuerint mandata tabellis:

'irascor, quoniam's, lente, moratus heri. /

an tibi nescio quae visast formosior? [...]'/

aut dixit: 'venies hodie, cessabimus una...' (Prop. 3.23.11-13, 15)

"Perhaps those tablets carried the following messages:

28 Cf. Ac nonnullae eius rei praetermissae occasiones Caesari videbantur, quod certi saepe flaverant venti, quibus necessario committendum existimabat (Caes. Civ. 3.25.1). 
'I'm so pissed, you loser! Why were you late yesterday?

You think you've found a hotter girlfriend?'

$[\ldots]$

Or they said: 'You'll come today, we'll relax together..."'

Ovid's Hero similarly insinuates unfaithfulness: o utinam venias! [...] / causaque sit certe femina nulla morae! ("Oh, I wish that you'd come, or that it's [...] certainly no woman that keeps you there"; Ov. Epist. 19.115-116). She knows that those are merely delusions and that she has no grounds for suspicion. Separation, distance, and delay make her afraid: cogit et absentes plura timere locus. [...] / nos tam vana movet, quam facta iniuria fallit ("And being absent makes the heart more fearful. [...] Baseless suspicions upset me as much as an affair I'm ignorant of would do"; 19.110-113). Caesar acts in the same way. In this case, Lucan's intertextual play with Ovid's double letters 18 and 19, where Hero's allegations are contrasted with the attitude of Leander himself, allows us to look at Caesar's fears of Antony's faithfulness from a broader perspective.

Because of Hero's conflicting feelings, we have two images of Leander in her letter. When she complains about him, he is portrayed as being tardy, overcautious, or frightened, any of which prolongs delay; ${ }^{29}$ she even implies that he may be unfaithful. When she admonishes him, he appears as a devoted and reckless young man who wants to join her as soon as possible. That second characterisation corresponds to the image of Leander from his letter. He cannot bear separation (invitus [...] moror, Ov. Epist. 18.124); ${ }^{30}$ the only delay he wishes for is the one at her side (ubi dulce morari est, 209). On one hand, he knows he will not be able to cross the stormy sea, so he awaits better weather, on the other, he is ready, if the storm does not calm down, to risk his life by crossing.

In Caesar's speech Antony resembles that "former" Leander. Caesar's insinuation of his officer's disloyalty even has the narrator's sanction. As audax, Antony was thinking already, while in Brundisium, about the "Leucadian war" (Lucan. 5.478-479). The audience of the poem, however, can read Caesar's and narrator's words through the prism of Ovid's letters as empty fears and unsubstantiated allegations. The Neronian narrator cannot be trusted both because he projects his knowledge of the future on the past and because he is too much involved in the events he recounts (only a few lines above he has blamed Caesar for the war, justifying Pompey, in an emotional apostrophe to the latter, 5.472-475). Caesar, in turn, is too eager for war to have a sound judgement. They both behave similarly to the passionate Hero implying unfaithfulness in Leander. The armies from Italy eventually arrive once the sea has calmed down. Antony, contrary to Leander, is not characterised by temeritas, which is going to be displayed by Caesar himself.

The audience might expect that Antony will continue to play the role of Leander, whom V. Rimell (2006: p. 188) describes as "something of a cliché, a prototype miles amator, in Ovidian love elegy”. But surprisingly, Lucan casts Caesar himself in it. In order to

29 Mora appears three times already in the first 10 lines: Ov. Epist. 19.3, 8, 10; it also constitutes the last word of the letter (210: moras).

30 Leander's letter, too, virtually begins with delay forced upon him: morantur, Ov. Epist. 18.5; mora also, like in Hero's case, closes the elegy (218). 
break the inertia and fearing disloyalty from his officer, Caesar decides to risk an attempt to cross the Adriatic at night. He must transform from a mistress, domina, served by her lover, into a lover himself, not only into a miles, but also into a servus amator wishing to join his beloved:

dum se desse deis ac non sibi numina credit,

sponte per incautas audet temptare tenebras

quod iussi timuere fretum, temeraria prono

expertus cessisse deo, fluctusque verendos

classibus exigua sperat superare carina. (Lucan. 5.449-503)

“... and, when he saw him still delay, believing that Heaven was more true to him than he to Heaven, he ventured in the dangerous darkness to defy the sea, thus doing of his own accord what others had feared to do when bidden. He knew by experience that rashness succeeds when Heaven favours, and hoped to surmount in a little boat the waves that even fleets must fear."

J. Farrell (1998: p. 324) writes about Heroides: "The man's role is that of reader, who is then to act on what he has read." When Caesar's role changes, he acts in response to an imaginary letter that would be similar to his urgent words. The author of such a letter are the soldiers in Brundisium who, in Plutarch's Life of Caesar (37.8-9, quoted above), sit on the rocks and look for ships. Lucan's audience may have known this scene.

Caesar acts in the way Hero wants Leander to act - characterised by audacia ${ }^{31}$ and the already-mentioned temeritas (see also virtus temeria, 5.682, from the troops' speech after Caesar's return). He insists on sailing in spite of the helmsman's warnings that even a shipwrecked sailor (naufragus, 5.573) will not reach the other side of the coast. Such a shift undermines the role Caesar plays before the soldiers, and therefore the role he has imposed on them. R. O. A. M. Lyne (1979: p. 118) writes about servitium amoris in Propertius' and Tibullus' works: “... both imply through the image that their love for the person in question involves degradation [emphasis by Lyne] - and degradation, be it noted, for the party whom we should in fact expect to be the dominant one." That remark can be applied both to the obedient troops and to Caesar himself during his attempt to cross the Adriatic. An external symbol of his degradation is the plebeian robe he dons (plebeio tectus amictu, Lucan. 5.538) and the small boat (exigua [...] carina, 503) of the poor helmsman which he sails. The narrator compares him also to a slave - even a servant would hardly dare such a crossing: vix famulis audenda parat, 509. In the context of elegiac references, this journey can be interpreted as the realisation of servitium amoris (the word servus is largely avoided by Roman epic writers, and the more sublime famulus is used instead). ${ }^{32}$

The attempt to cross the Adriatic proves to be unsuccessful. Therefore, we do not witness the scene of reunion between lovers (Caesar and his soldiers in Brundisium)

31 Cf. Ov. Epist. 18.49, 195; 19.89, 159.

32 See e.g. Watson (1985: pp. 434-436). 
separated by the sea. Instead, there is a scene of Caesar's return to the camp after the storm. The troops on the Greek coast do not notice Caesar's degradation:

circumfusa duci fleuit gemituque suorum

et non ingratis incessit turba querellis.

quo te, dure, tulit virtus temeraria, Caesar,

aut quae nos viles animas in fata relinquens

inuitis spargenda dabas tua membra procellis?

cum tot in hac anima populorum vita salusque

pendeat et tantus caput hoc sibi fecerit orbis,

saevitia est voluisse mori. nullusne tuorum

emeruit comitum fatis non posse superstes

esse tuis? cum te raperet mare, corpora segnis

nostra sopor tenuit. pudet, heu! tibi causa petendae

haec fuit Hesperiae, visum est quod mittere quemquam

tam saevo crudele mari. sors ultima rerum

in dubios casus et prona pericula morti

praecipitare solet: mundi iam summa tenentem

permisisse mari tantum! quid numina lassas?

sufficit ad fatum belli fauor iste laborque

Fortunae, quod te nostris inpegit harenis?

hine usus placuere deum, non rector ut orbis

nec dominus rerum, sed felix naufragus esses?' (5.680-699)

"Crowding round their leader, they shed tears and assailed him with lament and expostulations not unpleasing to his ear. 'Hardhearted Caesar, to what lengths your rash courage has carried you! And at the mercy of what fate did you leave our worthless lives, when you gave your limbs to be torn in pieces by the reluctant winds? When the existence and safety of so many nations depend upon your single life, and so large a part of the world has chosen you for its head, it is cruel of you to court death. Did none of your comrades deserve the honour of being prevented from surviving your end? While the sea drove you along, our limbs were held by slothful sleep; you put us to the blush. You made for Italy yourself, because you deemed it heartless to bid any other cross such a stormy sea. In general it is utter despair that hurls men into jeopardy and danger that runs straight to death; but that you, who are now master of the world, should grant such licence to the sea! Why do you overtask the goodwill of Heaven? Fortune has hurled you here upon the shore; for the issue of the war, are you content with that instance of her favour and assistance? Is this the use you prefer to make of Heaven, that you should be, not the ruler of the world or the master of mankind, but a shipwrecked wretch who escapes from drowning?"”

The speech resembles that of Craterus addressed to Alexander in Curtius Rufus' Histories of Alexander the Great (9.6.6-14). ${ }^{33}$ Fantham's observation (1985: p. 131), quoted

33 Heitland had already compared those passages (Introduction to Haskins 1887: p. lxxi); in the similarities he finds the influence of a rschool of rhetoric - "school commonplaces"; also Barratt (1979: ad 682-699); 
above, that "... the soldiers act like erastai toward their beloved Caesar...", concerns these lines too. Furthermore, their lament (querellae Lucan. 5.681), flattering to the leader, also bears references to erotic poetry, as noted at the beginning of the article.

The soldiers start the speech with the vocative dure - seldom used in epic poetry, and potentially evoking the image of a cruel mistress, dura puella, addressed by her lover. ${ }^{34}$ Apart from that vocative the speech also features saevitia (687), the adjective crudelis (692), and the interjection heu (690). Matthews (2008: ad 682) notes that Caesar can be perceived here as a woman, but his men in the following lines are "cast in the role of (the abandoned) female heroine of elegy". However, the complaint, querela, is not only the expression of the heroines in the Heroides, but also a significant part of the expression of the male lyrical subject in Roman elegy. ${ }^{35}$ The aforementioned words also belong to his vocabulary, as he is separated from his mistress (they can refer directly to the mistress or to anything connected with her). ${ }^{36}$ It is worth quoting here the words of S. L. James (2003: p. 110), describing a lover's lament:

“... he is perpetually wretched (tristis, miser) and weeping (fleo, lacrimans) either because Cupid, Venus, and his girl are hard, savage, and cruel (dura, saeva, crudelis) or because he is separated from his beloved. [...] He adverts to his suffering constantly in interjections of woe (heu, ei, io) and descriptions of his unhappy condition (tristitia, miseria). He proclaims in lament (queror, querela) his absolute devotion to the puella, his condition of degradation, servitude, or captivity to his domina... All these topoi are expressed in the querela."

Such an attitude is clearly shown in the words of the soldiers who do not notice Caesar's degradation.

During their mutiny in Book 4 they seemed aware for a while of their true role in Caesar's actions:

Nos fatum sciat esse suum. Licet omne deorum

obsequium speres, irato milite, Caesar,

pax erit. (Lucan. 5.293-295)

"Let Caesar learn that we are his destiny; though he hope for entire compliance from the gods, yet the anger of his soldiers will bring peace."

Fantham (1985: p. 130-131) - the similarities stem from the same rhetorical tradition based on the narratives about Alexander; Matthews (2008: p. 17 and ad 678-99).

34 For dure in epic poetry see Barratt (1979: ad loc.). Fredrick (1997: p. 174) briefly describes dura puella: "The dura puella [...] is separated from the amator by an almost endless series of barriers (doors, rivers, dinner parties, old nurses, voyages abroad, eunuchs). Behind these lies her sexual experience with other men..." In Plutarch's biography (Caes. 38.7), the troops' accusations even include envy for those towards

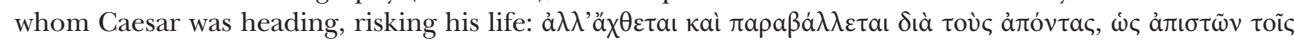

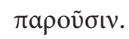

35 For the vocabulary of an elegiac lament see James (2003: pp. 108-152; in particular 110-111).

36 James (2003: p. 114) notes, for example, that the word durus in Propertius' writings usually refers to puella, in Tibullus' and Ovid's works more commonly to the obstacles the lover is facing. 
However, he corrects those beliefs - from his point of view - that are wrong: mankind, which even the gods do not care about, lives only for a handful of men (humanum paucis vivit genus, 5.343). The soldiers adopt such a viewpoint and, to Caesar's surprise, humbly accept their punishment (vicit patientia saevi / spem ducis, 5.369-370), assuming the role imposed on them. After this brief mutiny they appear in their prescribed role, remaining the lovers who must try to win their mistress' heart (in the political reality - that of the ruler of the world, dominus rerum, 5.699), the servants whose life without their beloved leader, master, is meaningless. They are ready for any type of sacrifice for him and would rather die than live after his death.

What is interesting is the repetition of viles animas at the beginning of two speeches of the soldiers: during the mutiny the expression includes Caesar's viewpoint, and constitutes the army's objection towards the way it is treated:

\begin{abstract}
quaeris terraque marique
his ferrum iugulis animasque effundere viles

quolibet hoste paras... (Lucan. 5.262-264)

"You search over land and sea for swords to pierce our hearts, and you are ready to spill our worthless lives by the hand of any foe."
\end{abstract}

In their lament, the phrase nos viles animas (5.683) demonstrates complete surrender, presents the way in which the troops perceive themselves. ${ }^{37}$ It is also worth noting the words saevitia/saevus - in the narrator's discourse depicting the mutiny, Caesar is saevus as the one committing a crime and severely punishing the soldiers (Lucan. 5.307-308: vult omnia certe / a se saeva peti; 5.314-315: saeve, quid insequeris?; 5.364-365: tremuit saeva sub voce minantis / volgus iners - saeva sub voce may be a focalization from the mutineers' perspective here; and aforementioned 5.369-370); whereas on the Greek coast severity, saevitia, becomes not what Caesar requires of them, but the fact that he could withdraw his demands: the severity is Caesar's risking of his own life (Lucan. 5.685-687). ${ }^{38}$ Moreover the sea that Caesar struggled with is now ferocious (saevo [...] mari, 5.692). In elegy, on a lover's lips, the terms durus, saevus or crudelis in reference to a mistress (directly or indirectly $)^{39}$ contain, apart from his lament and grievances, also an element of rebellion, even if it is only a temporary, verbal, or imagined one. In Lucan's poem, that type of dissent seems to fade away.

In Roman love elegy, the lyrical subject rejects the typical hierarchy of Roman values, wherein a military career, as a part of a political career, was the top goal; in the militia

37 Caesar speaks of Labienus, who took Pompey's side: fortis in armis / Caesareis Labienus erat: nunc transfuga vilis / cum duce praelato terras atque aequora lustrat, 5.345-347); even if the soldiers under Caesar's leadership do not matter and live for the individual, they are at least brave, fighting and not merely inspecting the land.

38 See also Fratantuono (2012: p. 208).

39 Cf. the use of crudelis in Propertius' elegy 1.8, where the lyrical subject tries to prevent his puella from sailing to his rival - he both threatens her, stanking on the empty shore (et me defixum vacua patiatur in ora / crudelem infesta saepe vocare manu! 15-16) and wishes her a safe journey: sit Galatea tuae non aliena viae (18). 
amoris topos, both its components are either contrasted with each other or equated, or militia is subject to amor; Lucan, using this topos with regard to the army, seems to be sanctioning the original hierarchy again, in which amor is subjected to militia. During the soldiers' mutiny Lucan's narrator expresses his ambivalent attitude towards their actions:

Sic eat, o superi: quando pietasque fidesque

destituunt moresque malos sperare relictum est, finem civili faciat discordia bello. (Lucan. 5.297-299)

"So be it, ye gods! Since duty and loyalty are no more and our only remaining hope is in wickedness, let mutiny make an end of civil war."

Under normal circumstances pietas and fides are desirable, but the narrator's hope for the end of the civil war lies in bad conduct (mores malos) and discord (discordia). As far as loyalty towards the commander is considered highly desirable, the problem arises with militia itself, as it is a crime - scelus, nefas - which is only exacerbated by amor. This topos is interconnected with another, namely servitium amoris - an elegiac lover "fighting" in his mistress' camp, willing to obey her orders, becomes also her servant, and militia and servitium are merged together. But once we consider the real sphere of militia, we encounter an extremely dangerous situation, where soldiers as lovers and slaves will obey any order of their leader. While declarations of the elegiac amator are often not followed by deeds, constituting only an element of the discourse, ${ }^{40}$ the fanaticism of Caesar's troops goes far beyond words.

Littlewood (2016) considered Lucan's elegiac references in the context of blurring the boundary between the public and the private during the civil war. Matthews, summing up his above-mentioned article, states:

"The intertexts help to emphasise Caesar's strong feelings at this point in the poem and to highlight his recklessness in attempting to cross the sea to Brundisium and his eventual good Fortune in being rescued from the storm. Furthermore, it contributes to the general theme in the poem of Caesar's men as his erastai." (Matthews 2011: p. 137)

But this is not all. As I have tried to show above, by the intertextual play with Roman love poetry a dissonance between the self-presentation and self-creation of Caesar (constructed on the basis of how others relate to him) and the actions he must undertake is shown very clearly. Firstly, he (for the poem's audience who decipher the references to Roman elegy) presents himself as a demanding, elegiac domina. He expects Antony to arrive as soon as possible regardless of the dangers, and he does not doubt that his

40 In Propertius' elegy 3.16 a nocturnal journey from Rome to Tibur becomes a great challenge for the lover, one that may end in his death and one which he perhaps would not have undertaken (I omit here more complex interpretations of the elegy, see e.g. Cairns 2010). For servitium amoris as a fantasy or a metaphor see James (2003: pp. 145-150): “...it consists of prominent lamentation but very little work” (147). 
troops will come at any cost. The soldiers in his eyes are like a lover serving his mistress. ${ }^{41}$ However, when Antony does not arrive, Caesar decides to sail to his soldiers, and in this way his elegiac role changes. The elegiac references, this time in the narrator's discourse, undermine the roles that Caesar assigned to himself and his soldiers. His crossing can be interpreted as a superhuman deed worthy of an epic hero and a challenge to the gods. When we look at it through the prism of Roman elegy, Caesar, trying to cross the Adriatic, is demoted to an elegiac lover as a slave.

In the end, it turns out that the soldiers during the mutiny were right. Their life is not meaningless, they are not a mass living only for the few, as Caesar stated in his speech to the mutineers. The mutiny, however, was suppressed and the troops on the Greek coast, having already undergone complete degradation, stop being aware that it is he who needs them, "longing" primarily for the crime which will give him power. They do not perceive that Caesar's role has changed. According to Matthews, they act like an abandoned woman, but in my opinion they still remain in the role of elegiac lovers, imposed on them by Caesar. Leander wished to be either a lucky daredevil (felix audacia, Ov. Epist. 18.195) who will safely join Hero, or a dead castaway on his beloved's shore (naufraga membra, 198). Caesar is for his soldiers a fortunate shipwreck survivor (felix naufragus, Lucan. 5.699), not only because he safely reached the shore, but also because due to their slavish attitude (which they forget about) he can remain rector orbis and dominus rerum.

\section{Bibliography}

Baca, A. R. (1971). The Themes of querela and lacrimae in Ovid's Heroides. Emerita, 39, 195-201. Barratt, P. (1979). M. Annaei Lucani Belli civilis liber V: A Commentary. Amsterdam: Hakkert.

Bramble, J. (1982). Lucan. In E. J. Kenny, \& W. V. Clausen (Eds.), The Cambridge History of Classical Literature, 2: Latin Literature (pp. 533-557). Cambridge: University Press.

Bruère, R. T. (1951). Lucan's Cornelia. Classical Philology, 46, 221-236.

Cairns, F. (1989). Virgil's Augustan epic. Cambridge: University Press.

Cairns, F. (2010). The Mistress's Midnight Summons: Propertius 3.16. Hermes, 138, 70-91.

Caston, R. R. (2011). Lucan's Elegiac Moments. In P. Asso (Ed.), Brill's Companion to Lucan (pp. 133-152). Leiden: Brill.

Copley, F. O. (1947). Servitium amoris in the Roman Elegists. Transactions and Proceedings of the American Philological Association, 78, 285-300.

Duff, J. D. (Ed.). (1928). Lucan: The Civil War. London: William Heinemann.

Fantham, E. (1985). Caesar and the Mutiny: Lucan's Reshaping of the Historical Tradition in De bello civili 5. 237-373. Classical Philology, 80, 119-131.

Farrell, J. (1998). Reading and Writing the Heroides. Harvard Studies in Classical Philology, 98, 307-338.

41 Petreius, breaking a temporary truce between the armies in Spain, even speaks of Caesar as the master of slaves: ibitis ad dominum [...], / utque habeat famulos nullo discrimine Caesar (4.217-218); cf. Cato on Pompey's soldiers renouncing the fight after his master's death: o famuli turpes, domini post fata prioris itis ad heredem (Lucan. 9.274-275). 
Fratantuono, L. (2012). Madness Triumphant: A Reading of Lucan's Pharsalia. Lanham, MD: Lexington Books.

Fredrick, D. (1997). Reading Broken Skin: Violence in Roman Elegy. In J. Hallett, \& M. Skinner (Eds.), Roman Sexualities (pp. 172-193). Princeton: University Press.

Gildenhard, I. (2006). Reckoning with Tyranny: Greek Thoughts on Caesar in Cicero's Letters to Atticus in Early 49. In S. Lewis (Ed.), Ancient Tyranny (pp. 197-207). Edinburgh: University Press.

Hardie, Ph. R. (2002). Ovid's Poetics of Illusion. Cambridge: University Press.

Haskins, Ch. H. (Ed.). (1887). M. Annci Lucani Pharsalia (with an introd. by W. E. Heitland). London: G. Bell and Sons.

Henderson, J. (1987). Lucan/The World at War. Ramus, 16, 122-164.

Hutchinson, G. O. (2013). Greek to Latin: Frameworks and Contexts for Intertextuality. Oxford - New York: Oxford University Press.

James, S. L. (2003). Learned Girls and Male Persuasion: Gender and Reading in Roman Love Elegy. Berkeley: University of California Press.

Katz, V. (Transl.). (2004). The Complete Elegies of Sextus Propertius. Princeton: University Press.

Kenney, E. J. (Ed.). (1996). Ovid: Heroides XVI-XXI. Cambridge: University Press.

Leigh, M. (1997). Lucan: Spectacle and Engagement (Oxford Classical Monographs). Oxford: Clarendon Press.

Littlewood, C. (2016). Elegy and Epic in Lucan's Bellum Civile. In A. M. Keith, \& J. Edmondson (Eds.), Roman Literary Cultures. Domestic Politics, Revolutionary Poetics, Civic Spectacle (pp. 159184). Toronto: University Press.

Lyne, R. O. A. M. (1979). Servitium Amoris. The Classical Quarterly, 29, 117-130.

Masters, J. (1992). Poetry and civil war in Lucan's Bellum Civile. Cambridge: University Press.

Matthews, M. (2011). The Influence of Roman Love Poetry (and the Merging of Masculine and Feminine) in Lucan's Portrayal of Caesar in De Bello Civili 5.476-497. Materiali e discussioni per l'analisi dei testi classici, 66, 121-138.

Matthews, M. (Ed.). (2008). Caesar and the Storm: A Commentary on Lucan, De Bello Civili, Book 5, lines 476-721. Oxford - New York: Peter Lang.

McCune, B. C. (2014). Lucan's Militia Amoris: Elegiac Expectations in the Bellum Civile. Classical Journal, 109, 171-198.

McKeown, J. C. (1995). Militat Omnis Amans. The Classical Journal, 90, 295-304.

Murgatroyd, P. (1981). Servitium Amoris and the Roman Elegists. Latomus, 40, 589-606.

Murgatroyd, P., Parker, S., \& Reeves, B. (2017). Ovid's Heroides: A New Translation and Critical Essays. London - New York: Routledge.

Pelling, Ch. (Transl.). (2011). Plutarch: Caesar. Oxford - New York: Oxford University Press.

Perrin B. (Ed.). (1919). Plutarch: Lives, VII: Demosthenes and Cicero. Alexander and Caesar. London: William Heinemann.

Pichon, R. (1902). De sermone amatorio apud Latinos elegiarum scriptores. Paris: Hachette.

Pitcher, L.V. (2008). A Perfect Storm? Caesar and his Audiences at Lucan 5.504-702. The Classical Quarterly, 58, 243-249.

Richardson, Jr., L. (Ed.). (2006). Propertius. Elegies I-IV. Norman, OK: University of Oklahoma Press. 
Rimell, V. (2006). Ovid's Lovers: Desire, Difference, and the Poetic Imagination. Cambridge: University Press.

Sannicandro, L. (2010). I personaggi femminili del Bellum Civile di Lucano. Rahden, Westfalia: VML Verlag Marie Leidorf.

Saylor, C. (1967). Querelae: Propertius' Distinctive, Technical Name for his Elegy. Agon, 1, 142-149.

Shackleton Bailey, D. R. (Ed.). (1968). Cicero's Letters to Atticus, IV: 49 B.C., 133-210 (Books VII.10 $-X)$. Cambridge: University Press.

Showerman, G. (Ed.). (1914). Ovid: Heroides. Amores. London: William Heinemann.

Watson, P. (1985). Axelson Revisited: The Selection of Vocabulary in Latin Poetry. The Classical Quarterly, 35, 430-448.

Weiden Boyd, B. (1997). Ovid's Literary Loves: Influence and Innovation in the Amores. Ann Arbor: University of Michigan Press.

Dr Mariusz Plago / mariusz.plago@uwr.edu.pl

Institute of Classical, Mediterranean and Oriental Studies

University of Wroclaw

UI. Komuny Paryskiej 21, Pl-50-451 Wrocław, Poland 
